\title{
UNITED NATION CONVENTION AND ISLAMIC APPROACH ON THE RIGHT OF PERSONS WITH DISABILITIES: A Comparison
}

\author{
Khairil Azmin Mokhtar and Ikmal Hisham Md.Tah \\ International Islamic University Malaysia \\ ka_mokhtar@iium.edu.my; ikmalhmt@gmail.com
}

\begin{abstract}
Persons with disabilities, either acquired or developed at some stages of his life due to factors such as injury and disease, are still a person with the same legal status and rights as individuals who do not have any disability. This paper, through conceptual and doctrinal analysis, explores the similarities and differences between human rights based's approach and Shariah's approach towards people with disability. People with disability have equal right to live and to have a noble livelihood. The Convention on Rights of People with Disabilities of the United Nations has adopted the concept of human rights-based approach which requires people with disability tobe treated in a proper way. The convention believes that this group should not be treated differently and given similar opportunity to be developed and progressed as any other human being. On the same note, Islam sees disability as morally neutral. It is seen neither as a blessing nor as a curse. Accordingly, disability is accepted as being an inevitable part of the human condition. It is simply a fact of life which has to be addressed appropriately by the society of the day. In Islam people with disabilities are not being arbitrarily segregated and being discriminated unjustly. They should be given equal opportunity to progress and develop their potential just like any other human being. The final analysis shows that there is harmonious interpretation between Western human right and Islamic jurisprudence to protect this minority.

Kaum difabel baik sejak lahir maupun karena faktor tertentu seperti cidera atau penyakit, masih memiliki status hukum dan hak yang sama dengan individu yang tidak memiliki kecacatan. Makalah ini, melalui analisis konseptual dan doktrin, mengeksplorasi persamaan dan perbedaan antara pendekatan berbasis
\end{abstract}


hak asasi manusia dan pendekatan Syariah terhadap penyandang disabilitas. Kaum difabel memiliki hak yang sama untuk hidup dan memiliki penghidupan yang mulia. Konvensi PBB tentang Hak-hak Kaum Difabel telah mengadopsi konsep pendekatan berbasis hak asasi manusia yang mengharuskan penyandang disabilitas diperlakukan secara pantas. Konvensi tersebut meyakinkan bahwa kelompok ini tidak boleh diperlakukan secara berbeda dan diberi kesempatan serupa untuk berkembang seperti manusia lainnya. Sama halnya, Islam memandang disabilitas sebagai netral secara moral. Hal ini dilihat tidak sebagai berkat atau sebagai kutukan. Dengan demikian, disabilitas diterima sebagai bagian tak terelakkan dari kondisi manusia. Ini hanyalah sebuah fakta kehidupan yang harus ditangani secara tepat oleh masyarakat saat ini. Dalam Islam kaum difabel tidak dipisahkan secara sewenang-wenang dan didiskriminasi secara tidak adil. Mereka harus diberi kesempatan yang sama untuk maju dan mengembangkan potensinya seperti manusia lainnya. Hasil analisis menunjukkan bahwa ada interpretasi yang harmonis mengenai hak asasi manusia antara Barat dan yurisprudensi Islam untuk melindungi minoritas ini.

Keywords: disability, human rights-based approach, Islamic approach, social model

\section{Introduction}

God has created humanity with their unique features and specialities. Each is unique in his or her way. Only God is perfect; the human being is not. Imperfection is the indispensable attribute of a person. Thus, an individual who has a disability, either acquired or developed, is still a person with the same legal status and rights as individuals who do not have any disability. This paper, through conceptual and doctrinal analysis, explores the similarities and differences between human rights based approach and Sharia's approach towards people with disability.

People with disabilities have equal right to live and to have a dignified livelihood. The United Nations Convention on Rights of People with Disabilities (CRPD) has adopted the concept of human rights-based approach which requires people with disability treated in a proper way. The convention believes that this group should not be treated differently and given similar opportunity to be developed and progressed as any other human being. On the same note, Islam sees disability as morally neutral. It is seen neither as a blessing nor curse.

Accordingly, disability accepted as being an inevitable part of the human condition. It is simply a fact of life which has to be addressed appropriately by the society of the day. In Islam people with disabilities are not being arbitrarily 
segregated and being discriminated unjustly. They should give equal opportunity to progress and develop their potential just like any other human being. The final analysis shows that there is harmonious interpretation between Western and Islamic jurisprudence to protect this minority group.

\section{Western Approaches towards Persons with Disabilities}

Initially, according to the medical model of disability, the persons with disability are being viewed as someone needed to cured and rehabilitate which consistent with the. Due to continuous struggle and fighting by individual, scholars and civil society organizations, the understanding of disability issues has a change to adopt the social model. This model based on the mutual understanding where people with disabilities, are being denied their rights not by the medical reason, but through the attitudinal of society and environmental barriers creating to neglect and isolate them from mainstream society (Oliver \& Barnes, 2012: 21-23). The existence of the CRPD has become a catalyst for developing a better understanding of the relationship between disability studies and law through human rights approach. Human rights approach has become significant to promote and protect the rights of disabled people around the globe.

\section{Human Rights Approach and Its Suitability}

Human rights approach towards disability has become the main agenda within international and domestic legal frameworks. It allows disabled people to be treated as 'subjects' rather than 'objects' where they shall be respected with inherent dignity and accommodating their differences (Quinn \& Degener, 2002: 1). Human rights approach has strengthened the individual aspects and disability movements which included the various dimension of human rights such as civil, political, economic, social, culture and environment obligations (Johnston, 2001: 23).

This approach is the best representing the need to protect the rights under the international and domestic jurisdiction. It will allow disabled people being respected by others by their individual personal capacity, interaction with others and involvement with society. The issues and violations facing disabled people are explained to show negative attitude from society, and environmental barriers are facing them are crucial and affected their rights inherently. 
Degener (2016) gives six reasons why human rights approach is the most suitable approach in promoting and realizing rights of persons with disabilities.

First, human rights views impairment does not defeat the condition of the person overall. Unlike social models which view impairment as the social construct perspectives, the human rights approach view disability as moral principle and value specially address the concern of individual as stated in the preamble of CRPD. The idea of 'inherent dignity' stated under the preamble Article 1 CRPD applies to everyone regardless any disabilities. Furthermore, Article 12 requires equal recognition for persons with disabilities which applies to everyone.

Second, the human rights approach allows the inclusion of first and second generation of human rights as describe under the CRPD. The treaty combines the existence between civil, political rights together with economics, social and culture. For example, the rights of equality under the laws (Article 12) can implement through rights of social service and independent living. The right of independent living (Article 19) requires inter-relation with rights to health, community and others.

Third, human rights view impairment as part of human diversity. While social model views disability through attitudinal and environment barrier of society, human rights approach view their impairment, pain and suffering by individual and society as part of human identity.

Fourth, human rights approach acknowledges identity issue. The social model has abandoned the identity ideas where people with disabilities allow them to identify their existence. The human rights approach believes identity is crucial for them to fight their rights, similar to other minority groups such as woman, indigenous people and others.

Fifth, human rights allow preventive policy. The preventive policy for impairment has been criticising by disability activists as stigmatization and a discriminatory practice for persons with disabilities due to an inclination towards the medical model. However, this preventive policy has been recognising under Article 25 where it required the equal access and specialised health care for persons with disabilities. It has shown that preventive policy for individuals with diabilities may view as promoting human rights that benefit this group for better and equal access to health services. 
Sixth, human rights model strive to achieve social justice. The existence of CRPD has allowed potential development of persons with disabilities through national agenda. Article 32 CRPD allows such international cooperation amongst disabled people organization (DPO) and various agencies to mainstreaming disability as development issues. With the latest Sustainable Development Goals (SDG) known as Transforming Our World: the 2030 Agenda for Sustainable Development promoted by United Nations, disabled people would have potential to be inclusive within society, and various aspects of sustainable development might incorporate within international and domestic development agenda (Sustainable Goals, 2015).

\section{The Main Concepts of Human Rights Approach to Disability}

Persons with disabilities, subsequently, have similar protection by law to be protected like other minority groups. The existence of international treaties like United Nations CRPD and its Optional Protocol and various domestic legislations have expanded the concept of human rights applicable to them. According to Marcia H. Rioux et al., Gerard Quinn, Theresia Degener and Michael A. Stein, the human rights approach consists of three main concepts namely dignity, equality and inclusion (Quinn \& Degener, 2002; Rioux et al., 2011; Stein, 2007).

\section{Dignity}

Dignity is defined as norms which prevail among human beings where everyone has equal values and self-worth towards everyone regardless of his or her economic and social status (Quinn \& Degener, 2002). It is derived from the ancient Roman word dignitas and dignitio. Dignitas refers to an individual who acquired significant political and social factor while dignitio means dignity given because of character as human being (Basser in Rioux et al, 2001).

The earliest UN Charter and UDHR have discussed the importance of dignity as a new approach within international human rights law framework. The UN Charter has reaffirmed the concept of dignity with the protection of human rights equals for everyone. Similarly, the preamble of UDHR has mentioned the word of 'inherent dignity' where everyone is born free and equal. Dignity also plays a crucial role in the first part of UDHR which discusses on categories of rights and a second part which describes a list of duties (McCrudden, 2008: 666). The ICCPR and ICESR both mutually concern on human dignity in a relationship with human rights. For example, Article 10 
ICCPR describes the deprivation of liberty while Article 13 ICESR discusses the right of education to dignity. The reference to dignity also becomes main part in most UN treaties such as CRC, Convention on Protection for migrant workers, and Protection against forced disappearance (McCrudden, 2008: 669). There are also several regional human rights treaties incorporated the concept of dignity as most important principles such as American Declaration on Rights and Duties of Man, African Charter on the Rights and Welfare of Children, Revised Arab Charter on Human Rights and ASEAN Charter (Basser in Rioux et al, 2001: 30-31).

The CRPD has become foundation within the preamble and several provisions which describe the important concept of inherent dignity as a basic principle of human rights. Article 1 described the purpose of the Convention 'to promote, protect and ensure full enjoyment of all human rights and fundamental people by all persons with disabilities, and to promote respect for their inherent dignity.' The concept of dignity also become a basic principle of CRPD under Article 3 and supported by other provisions such as Article 8 (awareness), Article 16 (Freedom from Exploitation, Violence, and Abuse), Article 24 (education) and Article 25 (health) (Basser in Rioux et al, 2001).

The contribution of disabled people is not just focusing on individual talent but also how every disabled people may contribute to the society and nation (Stein \& Stein, 2007: 1223). Basser argues the idea of dignity may apply to disabled within several requirements (Basser in Rioux et al, 2001: 27-28). First is the respect of the physical integrity of the person. Secondly, an individual must react according to their personality traits. Thirdly, any disabled people must be allowed to express themselves and allowing them to make a choice. Finally, every disabled people needed to share similar and fair treatment between members of the society.

\section{Capability Approach}

The idea of dignity protection for the person with disabilities has been influencing other scholars to propose an approach that might benefit the treatment for this group. For example, the concept of 'capabilities approach' is suited to apply in relation with human dignity (Al Saif, 2008: 75). Stein has applied the capabilities approach as proposed by Nussbaum (in Stein, 2007: 98-106) to improve the dignity and human rights of disabled people where this approach seek to improve the dignity of the individual to contribute to the development in a larger segment of society (Stein \& Stein, 2007: 1216). 
Nussbaum explained the capabilities approach in ten points of 'central capabilities' which applies to human dignity such as; life, bodily health, bodily integrity, senses, imagination and thought, emotions, practical reason, affiliation, other species, play and finally control over one's political environment (Nussbaum, 2000: 78-80). These capabilities are constructed together between internal and external factors of a person known as 'combined capabilities' (Nussbaum, 2000: 84-85). For example, disabled people are physically blind or deaf but lack support to pursue education because of a negative social construct such as lack of accessibility transportation to school, negative attitude about disability from society. In such case, State is not fulfilling the needs to support disabled people who explain under 'combined capabilities' (Stein, 2007: 100).

\section{Autonomy}

Besides capabilities, the concept of dignity is synonym related to the autonomy of person. Autonomy can be defined as 'every person has authority over himself that is grounded, not in his political or social role, not in any law or custom, but in the simple the fact that he alone can initiate his actions and manage his life' (Al Saif, 2008: 84). Immanuel Kant believes that dignity must come together with morality based on autonomy where every person, regardless of their characters, must treat everyone with humanity and mutual respect. The concept of autonomy of the individual is something precious within human rights discourse and remaining as 'non-negotiable' between individual and state (Mutua, 2016: 3).

Article 16 (4) of the CRPD has briefly described the State Parties needed to take appropriate measures for physical, cognitive and psychological recovery, rehabilitation and social reintegration of PWD from being abuse by looking into 'self-respect, dignity and autonomy of person.' The concept of autonomy, however, has one problem related to disability where it cannot be dependent on the ability of a single individual to act independently of others or to act rationally (Basser in Rioux et al, 2001: 26). They always observed and treated as 'object to be protected or pitied'. This stigmatisation is the consequence derived from the medical approach where persons with disabilities are considered as a problem and required clinical intervention (Degener, 2016: 14). It also leads towards the lack of understanding from state and society on every type of disabled suffered. This misunderstanding as noted by Quinn and Degener (2002) derived from 'social construct' describing disability through three premises. First, the label of disabilities itself is being accepted by society through their 
differences. For example, people tend to look at different characters of each where disabled people are prejudiced looking at their physical and appearance. Secondly, through this label, the 'authority' has usurped their power to select who are considered as disabled. It will lead towards 'controlling' the society for the sake of their power. Thirdly, the society views that disabled should 'set and keep people apart.' The majority of people believe that in everyday life, facilities, education, and employment are preferable to treat able-bodied rather than disabled (Degener, 2016: 15). Through these premises, it can be stated that disabled people have suffered misunderstanding from society through a misconception of dignity.

To fulfil dignity for people with disabilities, there are two requirements are crucial; meeting basic needs and implementation through law and policies (Basser in Rioux et al, 2001: 18). The basic needs for disabled people needed to fulfil, either in civil or political rights to ensure they can be treated similarly with non-disabled despite their limitations. It can be applied through empowerment of their inherent worth and develop their potential to contribute to society. The second requirement allows disabled people to involve in legal and administrative matters which affected their life and get recognition from authority and people. The principle of dignity required balancing the treatment towards individual rights and society needs through 'transformative potential of human dignity' (Basser in Rioux et al, 2001: 23). To expose the potential of disabled people, equal protection, and opportunity must be given. Therefore, it is important for dignity to be related to the concept of equality that will be discussed below.

\section{Equality and Justice}

Equality can be defined according to Oxford Dictionary as 'the fact of being equal in rights, status, advantage, etc.' (Oxford Dictionary, 2000). Historically, the concept of equality had been mentioned within several declarations such as 1776 American Declaration of Independence and 1789 French Declaration of the Rights of Man where the idea of everyone is created and born equally. This "enlightenment" concept believes everyone regardless of their status enjoys equal protection under the law. Other scholars such as Thomas Hobbes, John Locke, and Jean-Jacques Rousseau related the idea of equality with political freedom and democracy where everyone entitled to express their opinion and disagree with authority (Ansari \& Oseni, 2012). 


\section{Equality and Justice}

The concept of equality has mainly related to various important ones such as justice and non-discrimination (Dworkin, 1981). The prominent legal philosopher, Ronald Dworkin categorised equality into four (4) parts; equality of welfare, equality of resources, equality of freedom and political equality. Equality of welfare, based on his critics with distributive justice proposed by Rawls, believes that individual has preferences how goods, resources and opportunities should be distributed to others according to with their basic needs and characteristics. Dworkin has used the example of people with physical and mental disabilities needed more resources to achieve equality of welfare. On the part of equality of resources, he argued that the distribution must equally base on 'hypothetical auction' where people distributed the resources until everyone satisfied which known as 'envy test.' This test based on an equal division where everyone entitled with his or her 'own bundles, not others (Dworkin, 1981: 285).

However, this test is too simplistic since it would create problem for equal distribution towards person with disabilities. He further mentioned the story 'hypothetical insurance scheme' where the envy test would not apply where not everyone knows disabled might be at disadvantages position if market demand became the main subject in determining equality of resources. Rawls has become scholar that proposes this relationship through the concept of 'justice as fairness'. He further mentioned the 'original position' which based on two mechanisms; everyone has equal rights to basic liberties and secondly the arrangement of social justice to the society overall which well known as 'equality of opportunity'. Martha Nussbaum has criticised the theory of justice by Rawls stating that the social justice concept proposed by Rawls did not fulfil the demand of people with disabilities. She further argues that the 'original position' as proposed by Rawls will be disadvantages applicable towards people with mental disabilities where some of them might not be able to make own decision independently and subject for manipulation from others who are not acted on behalf of people with disabilities (Nussbaum, 2007: 11).

In the issue involving access to justice, various dilemma and problems face this group such as difficulties in accessing information for court or tribunal proceedings especially for Braille, sign language and various relevant reading formats, attitudinal barriers which include access towards legal representative and lack of legal capacity to instruct lawyers (Fynn, 2015: 49). These problems 
are inter-related with equality where they are being denied similar rights with others.

\section{Equality and Non-Discrimination}

Besides justice, the concept of equality and non-discrimination are co-existed together which prevail within the UN Charter itself (Rehman, n.d.: 402). Most of the UN treaties specify the norms of equality and nondiscrimination which addressed types and forms of discrimination suffered by minority groups including woman and child. The similar approach has also been explained under the UN CRPD where the concept of equality and non-discrimination has been upholding in the preamble of the convention to show the 'universality, indivisibility, interdependence and interrelatedness of all human rights.. the need for persons with disabilities to be guaranteed their full enjoyment without discrimination.' Hence, it is undeniable the significant link between equality and non-discrimination facing people with disabilities.

In relation towards disability, equality which related towards disability can be divided into three such as formal or juridical equality, substantive equality including equality of opportunity and equality of results or outcome (Rioux \& Riddle, 2011: 37). These three core concepts of equality would be consistent with human rights principle if all stakeholders agreed to the 'recognition of difference' amongst people with disabilities (Rioux \& Riddle, 2011: 341). It should be based on objective fact, the artificial distinction of different disability individual traits and re-constructing the legal and social inequalities facing this group (Rioux \& Riddle, 2011: 38).

Formal equality is relying on 'neutral application' of laws and treatment of everyone as similar and equal each other. Even this equality would ensure everyone competes and getting equal results. However, it ignored the differences facing disabled people. For example, not everyone can get equal voting rights and access to public facility same as non-disabled people. Therefore, the idea of formal equality becomes irrelevant when it comes to fulfilling the rights and needs of this minority group (Tah, 2013: 426:427).

The most relevant concept applicable is substantive equality which addresses systematic discrimination suffered by people with disabilities. This concept has broad application and valuable towards this group where it addressed most of the problems facing including the different types of disabilities and their basic rights and needs (Tah, 2013: 426:427). An individual with disabilities, for example, must be allowed to prove their talents and allowing 
for self-development might improve their situation to survive. For example, allowing people with physical employment to gain employment opportunity will enhance their dignity and economically benefit to the nation. A similar case is also applicable to the child with disabilities, where their talent might be discovered by education provider (school) which allowing them to show creativeness and potential of self-development (Shiuny, 2016: 49-50).

The concept of 'reasonable accommodation' for example shows a significant relationship between substantive equality and disability (Lord \& Brown in Rioux, 2011: 273). This concept can be defined as 'necessary and appropriate modification and adjustment not imposing a disproportionate or undue burden, where needed in a particular case, to ensure persons with disabilities the enjoyment or exercise on an equal basis with others...' (Article 2 UN CRPD). The inclusion of this concept has advanced the human rights discourse and obligation towards the UN Members States to fulfill, within their domestic legislation, policy and practice (Lord \& Brown in Rioux, 2011: 277). It will allow various stakeholders such as employers, education providers, health care providers, testing and qualification bodies, providers of goods and services and private entities to fulfill their duty by taking appropriate steps and measures to comply with international human rights standard on reasonable accommodation (Lord \& Brown in Rioux, 2011: 306).

The last part on equality involved equality of outcome. This category involved an understanding of disability through disabled peoples' involvements within society. It related with two main models such as pluralistic model and assimilative model (Rioux \& Riddle in Rioux et al., 2011: 51-52). The first model related with removing barriers to allow communication between disabled and non-disabled while assimilative model refers to allowing disabled people to get basic rights such as education, employment and community involvement which relevant for discussion below.

\section{Inclusion}

Inclusion can be defined as 'all people are entitled to full membership of human family (Jones in Rioux et al., 2011: 57). It allows every human being regardless normal or disabled people getting benefits from various skills and experience that might provide benefit to everyone. The principle of inclusion stated that every person is entitled to participate fully in society and enjoy similar rights and responsibilities. This principle of inclusion also associated with solidarity where every segment of society acknowledges

DOI: http://dx.doi.org/10.18860/ua.v17i1.3253 
their bilateral ties and obligations within society through understanding basic freedoms through substantive economic and social support (Quinn \& Degener, 2002: 19).

There are three most important principles towards inclusion for disabled people. Firstly, non-discriminatory attitude, secondly guarantees of access to participation in every area of life and thirdly facilitation of people with disabilities to limit the impact of the disability (Jones in Rioux et al., 2011: 58). These three most important principles are relevant and inter-related each other to show the involvement of people with disabilities, not just on issues affecting them, but also in various matters relating to politics, culture and economics. The political participation of people with disabilities is crucial to upholding the human rights approach where they are involved in democratic election and influence the process to choose a national leader (Waterstone in Rioux et al., 2011: 373). This basic right of political participation may observe through several international human rights instrument such as UDHR, ICCPR, the Standard Rules on the Equalization of Opportunities for Persons with Disabilities and finally the CRPD. Article 29 of the CRPD has ensured the non-discrimination and equal and effective participation of people with disabilities in the democratic process by providing appropriate facilities in the election process same with other voters (Waterstone in Rioux et al., 2011: 376). Through several cases in the US together with several provisions within American with Disabilities Act (ADA 1990), the court has taken 'third-level' of equality which includes accommodating different types of the voting process based on various kinds of disabilities (Waterstone in Rioux et al., 2011: 390). Consequently, it has improved the inclusion of disabled people within society in political participation or election process widely.

\section{Free from Violence}

The approach of life free from violence is also important to the principle of inclusion. People with disabilities are opened for abuse physically, psychologically, proprietary and negligence violence either occurred in the public or private sphere (Jimenez in Rioux et al., 2011: 402). This kind of violence occurred due to the social structure of society where the continuous discrimination and violence suffered. Traditionally, people with disabilities are associated with 'bad luck', too dependent on others and being portrayed as a weaker group that needed to be controlled by others. They become the object of charity for fundraising purpose, being the object of laughter, segregated in schools and 
hospitals. These experiences are available in some literature, movies, mass media and institutions in a country. It also leads towards the public tolerate on laws, political and religious institutions that sideline this group (Jimenez in Rioux et al., 2011: 404). Therefore, the experience in Inter-American Disability Convention by the initiative from Mexico which leads towards the proposal of establishment of the CRPD has the potential to address the global concern of society on violence issues facing people with disabilities (Jimenez in Rioux et al., 2011: 411, 417).

\section{Islam and Human Rights}

Islam requires that Muslims possess upright character and deal justly (Awan, 2017). The Glorious al Quran states the meaning of which:

"O ye who believe! stand out firmly for Allah, as witnesses to fair dealing, and let not the hatred of others to you make you swerve to wrong and depart from justice. Be just: that is next to piety: and fear Allah. For Allah is well-acquainted with all that ye do." (QS. al Maaidah: 87)

Islam recognizes an array of rights that humans, by virtue of being human, are entitled to and which, from a modern perspective, seem no different from many of the rights listed in the UDHR. For example, the right to life is a fundamental right in Islam for Muslims and non-Muslims alike. Similarly, a person, irrespective of their religion, has the right to be protected from physical harm unless they commit a crime that under Sharia would demand punishment. Rights to justice, equality, safety, security and human dignity are among those rights deemed indispensable in Islam. These are supplemented by further rights such as social solidarity, the right to education and own property, and freedom from slavery. It is not difficult to see why some would argue that many of the rights acknowledged and guaranteed in the UDHR are rights that had been granted in Islam some 14 centuries earlier (Hayatli, 2012: 3).

Islam requires believers to assist and protect vulnerable people and offers some mechanisms for their care and support. Islamic law has divinely mandated rights for individuals in their specific roles as spouse, parent, child, relative, neighbor, friend, and even foe. The model of rights and mutual responsibilities enshrined in Islam has a tremendous potential for personal and social reform (Hayatli, 2012: 3). 


\section{Muslim Countries and Convention on the Rights of Persons with Disabilities}

Convention on the Rights of Persons with Disabilities was opened for signature on 13 December 2006 also involving the ratification made by Muslims nations. As of October 2013, some Muslim nations have signed and ratified the CRPD, among them are Algeria, Egypt, Iran, Lebanon, Syria, and the United Arab Emirates. Unlike other Muslim countries, Iran and Egypt entered reservations to the Convention. Most of the conflicts between Islamic Law and the Convention's human rights framework were discussed throughout negotiations (Kinker, 2014).

Islamic law, which is rooted in revelations and religious texts, has the potential to be a dynamic force in the interpretation and application of human rights. Islamic law contains many of the same principles that animate the CRPD: non-discrimination, the right to life, assisting the needy, and empowering the weak, for instance. Compliance with the CRPD is widely based on non-discrimination provisions that require Islamic states to treat persons with disabilities as they do anyone else (Kinker, 2014). Since most Muslim nations turn to religious leaders for questions relating to both political issues and Islamic law, implementation of the CRPD thus will necessarily be influenced by religious views. It remains to be seen as to how much the Convention's obligations will be shaped by Shariah in Muslim countries (Kinker, 2014).

\section{Islam's Approach towards PWD}

Generally, Islam sees disability as morally neutral. It is seen neither as a blessing nor as a curse. Clearly, disability is therefore accepted as being an inevitable part of the human condition. It is simply a fact of life which has to be addressed appropriately by the society of the day (Musa, 2017). Everything that occurs, and all that exists in the world, are based on the will of God. In this regards, al Quran states the meaning of which. "We created man from a drop of quickening fluid to test him.” (QS. al Insaan: 27).

Islamic law does not perceive disabilities as an expression of divine anger, but rather as a grand test. Therefore, society should perceive disability as an act of God testing the faith of individuals to determine who can accept and tolerate their fate with gratitude and patience and those who are not (Turmusani, 2003: 52). The test extends beyond the disabled as it also has 
the effect on the whole community. In al Quran it is stated the meaning of which

"Do men think that they will be left (at ease) because they say, We believe, and that they will not be tested with affliction? We did test those before them, and Allah will certainly know (by bringing it to the world of reality) those who are true from those who are false" (QS. al Ankaboot: 2-3).

Even the atonement and redemption of sins may be attained through disability and disease as can be observed in a hadith of the Prophet Muhammad peace be upon him (PBUH) the meaning of which: "Whoever dies in any illness is a martyr" (Rispler-Chaim, 2007: 7).

In another hadith, the Prophet Muhammad (PBUH) stated: "No fatigue, no disease, nor sorrow, nor sadness, nor hurt, nor distress befalls a Muslim, even if it were a prick he receives from a thorn, but Allah expiates some of his sins for that" (Al Bukhari).

It can be concluded that this dual thinking-the classification of disability about the social functions it impacts, and the acceptance of disease as a condition of life-informs Sharia and the rights of the disabled. Islam requires Muslim to put aside prejudices and assumptions, and recognise that disability in and of itself is not necessarily a hindrance or disadvantage. No doubt, it causes the afflicted person far harder than someone who is not in his/her position. This is all the more reason why Muslims should make extra efforts to provide facilitation to people with disability by ensuring not only their physical comfort through appropriate measures but their mental and emotional ease as well (Pervez, 2017).

A basic standard of life includes the minimum essentials necessary for survival, such as food, clothing, shelter, and medical attention. Anyone suffering from deprivation of these economic necessities is entitled to receive aid to meet their needs. It is the duty of every Muslim with adequate means to give from their wealth, to eradicate poverty from society (Awan, 2017). Disabled persons have certain entitlements under Islamic law which must be met by the community. One hadith states the meaning of which: "Allah will remove his protection from the people of an area who allows one hungry person to wander amongst them" (Rispler-Chaim, 2007: 126).

Scholars have interpreted this verse to require state intervention when the needs of its disabled people are not met (Chaudri, 2003). In line with the view that the government has duties towards the PWD caliphs of Islam have been reported to fulfil the obligations through various measures. 'Umar ibn `Abdul `Aziz (r) asked rulers of the provinces to send him the names of all 
those who are blind, crippled, or with a chronic illness that prevented them from establishing salaah. So they sent him their names. He, in turn, ordered that every blind man should have an employee to guide and look after him and that every two chronically ill persons-those with special needs-be attended by a servant to serve and care for them (Al Jawzi, 2012). The same course was taken by the Umayyad caliph Al Waleed ibna `Abdul Malik (may Allah have mercy on him). The idea of the establishment of institutes or centres for the care of people with special needs was his. In AH 88 (707 CE), he ordered the creation of a foundation specialised in looking after them. Doctors and servants paid fixed stipends, were employed in this foundation. He granted a regular allowance to persons with disabilities, and told them, "Do not beg people." Thereby, he made them sufficient enough not to beg others. Also, he appointed employees to serve all those who were disabled, crippled, or blind (Yaqut, 2007).

\section{Treatment of the Persons with Disabilities under the Sharia}

The Sharia recognises various rights of persons with disabilities. The Prophet's behaviour toward disabled people is an example par excellence for us. In addition to greeting Abdullah ibn Umm Maktum with respect and humility, the Prophet PBUH, designated him as the Leader of Madinah many times in his absence. As far as the Prophet was concerned, Abdullah ibn Umm Maktoum's blindness was not a hindrance in his ability to carry out his duties (Yaqut, 2007).

Some Islamic jurists consider the disabled to be capable of exercising their political rights on an equal basis with others (Bulliet et al., 2013: 476). They also have the right to participate in as many aspects of the community's life as possible (Hassan, n.d.). Some scholars have suggested the only way for a state to fulfil the obligation of shura is to set up an elected assembly (Mawdudi, n.d.). Since one of these teachings or opinions separate out the disabled, it can be concluded that they are considered a part of the community with these rights to offer shura.

Islam permits freedom of expression (Hurriyat al ra'y), but subordinates such expression to the needs of the broader community. In al Quran it is stated the meaning of which

"Believers, do not say bad words against the idols lest they (pagans) in their hostility and ignorance say such words against God. We have made every nation's deeds seem attractive to them. One day they will all return to their Lord who will inform them of 
all that they have done" (QS. al An`aam: 108)

This idea-that societal order comes before any absolute freedom of expression is expressed in some verses of al Quran. In al Quran it is stated the meaning of which

"When there comes to them some matter touching (Public) safety or fear, they divulge it.

If they had only referred it to the Messenger, or to those charged with authority among them, the proper investigators would have Tested it from them (direct). Were it not for the Grace and Mercy of Allah unto you, all but a few of you would have fallen into the clutches of Satan" (QS. an Nisaa: 83).

Other limits on expression in the Islamic legal tradition include a prohibition on depictions of the Prophet Muhammad (PBUH). These prohibitions they do not uniquely burden the disabled. Instead, under Islamic law, the disabled possess rights of expression commensurate with the rest of society. The weak, blind, and impotent possess rights proportionate to the rest of society, to the extent public order and sacred images are involved.

Islam regards hard work and earning a livelihood as virtuous. The Prophet Muhammad (PBUH) has said, the meaning of which:

'No food is better to man than that which he earns through his manual work. Dawud, the Prophet of Allah, ate only out of his earnings from his manual work" (al Bukhari, 1: 543).

Proper payment for value received from work is similarly necessary.

The Prophet said, "Allah said, 'I will be an opponent to three types of people on the Day of Resurrection: 1. One who makes a covenant in My Name, but proves treacherous; 2 . One who sells a free person and eats his price; and -3. One who employs a laborer and takes full work from him but does not pay him for his labour" (al Bukhari, 3:36:470).

In al Quran, it is clearly stated the meaning of which: "To men is allotted what they earn, and to women what they earn” (QS. an Nisaa: 32).

Positions are entrusted to the capable regardless whether the person has a disability or not. If a person has a disability but is the most suitable person to do the task, then he should be assigned to undertake the task. In Islamic history, there are many examples like this. Abdallah Umm Maktum -a blind man who achieved fame as an avid student, eventual governor of Medina, leader of the prayer, and commander of military expeditions- was appointed for all these tasks by the Prophet Muhammad (PBUH) himself (Hamid, 1995). 
Another example is 'Atta Ibn Abi Rabah, who was lame as a result of paralysis, was considered the greatest Mufti in Mecca, and was honoured by the Caliph 'Abdul Malik Ibn Mawaran (Al Qaradawi, 2003).

Because Islamic law requires disabled persons to participate in the obligations incumbent upon all Muslims (to the extent of their ability) (al Qaradawi, 2003), knowledge of duties and Islamic law must somehow be taught (al Munajjid, n.d.). Sheikh al Azhar Dr Muhammad Sayyid Tantawi issued a fatwa which encouraged the use of sign language interpreters so that the deaf could understand the Friday sermon (Rispler-Chaim, 2007: 47). Indeed, such calls for education to fit the student are arguably a requirement of Islam (Dindang, n.d.).

\section{Conclusion}

While Western recognised the rights of disabled people as described above, Islam also does promote and protects the rights of disabled people accordingly. However, not many parties realised the contribution of Islamic World towards international human rights law. Some even critical with the involvement of international human rights within Muslim world where it lacks on promoting religious views out of individual liberalism and critical of involving Muslim scholars such which proposed 'harmonizing' Western and Islamic value on human rights (Farrar, 2005: 289-291). In the earlier period of establishment of UN, Muslim nations had played significant roles in promoting universal human rights by international standard despite some issues and challenges (Waltz, 2004: 799). Waltz has emphasised the importance of acknowledged of Muslim States contribution within international human rights sphere by stating:

"...Many human rights groups operating in the Middle East and Muslim world depend on international standards to anchor their claims for justice, representation, and an array of human rights, yet they appear generally unaware of the degree to which their states were invested in the negotiations that created those standards. The history of Muslim states in the negotiation process has been lost, or mislaid, and it is hoped this essay has contributed to its recovery. ...The role of Muslim states in creating the international human rights standards should neither be exaggerated nor discounted." (Waltz, 2004: 799).

Therefore, it is important not to neglect the view of human rights from the Islamic world that shapes the discourse globally. This discourse is crucial towards discussing the importance of human rights applicable to the people 
with disabilities. The existence of the UN CRPD, for example, has shown the potential to close the gap between human rights in Western and Islamic World. The implementation within Islamic countries is crucial to ensure the harmonisation between Islam and Western perspectives of disability rights can be materialised (Kinker, $2014: 65$ ).

The principles of dignity, equality and inclusion are significant within human rights approach towards disability. These principles at the general level are co-existed together by Islamic approach towards PWD. It can be observed that the human rights approach and Islamic perspectives towards PWD have congruent and parallel principles and views. This is favorable to people with disabilities who are facing various issues and challenges including human rights violations from society and their institutions.

\section{Bibliography}

Al Jawzi, Ibn. 2012. Disabled and Physically Impaired Muslims. Retrieved from http:// theislamicworkplace.com/disability-and-islam/

Al Munajjid, Muhammad. n.d. Fatwa No. 13793: Obligatory Duties For Those Who Are Deaf And Mute, Retrieved from http://islamqa.info/en/

Al Qaradawi, Yusuf. 2003. Fatwa: Taking Care Of The Disabled Retrieved from http://infad.usim.edu.my

Al Saif, Ahmad. 2008. The Rights of Disabled Persons and Discrimination: A Comparative Study in British, America and Saudi Arabian Disability Law. Unpublished PhD Thesis, Newcastle University.

Ansari, Abdul Haseeb \& Oseni, Umar A. 2012. Human Rights: Genesis and Perspectives. In Abdul Ghafur Hamid (Ed.), Human Rights Law: International, Malaysia and Islamic Perspectives. Selangor: Sweet Maxwell Asia.

Awan, Azra. 2017. Human Rights in Islam. Retrieved from https://www.whyislam. org/islam123/human-rights-in-islam/

Bernard, Catherine \& Hepple, Bob. 2000. Substantive Equality. Cambridge Law Journal 59 (3), 562-585.

Bulliet, Richard et al. 2013. The Princeton Encyclopedia of Islamic Political Thought Princeton: Princeton University Press.

Chaudri, Muhammad Sharif, 2003. What Is Islam: Gist of Teachings of Islam on All 
Important Fields of Human Life. Lahore: Snsam Education Foundation.

Degener, Theresia. 2016. Disability in a Human Rights Context. Laws 5(3), $1-24$.

Dindang, Norlain binti Muhammad. n.d. The Need for Islamic Education According to the Quran and Sunnah. Retrieved from http://islambasics.com/view. php?bkID=138\& chapter

Dworkin, Ronald. 1981. What is Equality? Part 2: Equality of Resources. Philosophy and Public Affairs 10 (4), 283-345.

Farrar, Salim Ali. 2005. Revealation, Philosophy and International Human Rights: Reconciling the Irreconcible? IIUM Law Journal 13 (2), 259-291.

Fynn, Eilionoir. 2015. Disabled Justice? Access to Justice and the UN Convention on the Rights of Persons with Disabilities. Burlington: Ashgate Publisher House.

Hadith Al Bukhari. 7:70:545. Retrieved from "Sunnah.Com, the Hadith of the Prophet Muhammad ", http://sunnah.com/urn/52930

Hamid, Abdul Wahid. 1995. Companion of The Prophet Vol 1. Retrieved from http://www.sunnah.org/history/Sahaba/maktum.html.

Hassan, Riffat. n.d. Are Human Rights Compatible with Islam? The Issue of the Rights of Women in Muslim Communities. Retrieved from http://www. religiousconsultation.org/hassan2.htm

Hayatli, Musab. 2012. Islam, International Law and the Protection of Refugees and Idps. Retrieved from http://www.fmreview.org/Human-Rights/hayatli.html

Johnston, David. 2001. An Introduction to Disability Studies. London: David Fulton Publishers.

Kinker, Brenton. 2014. An Evaluation of the Prospects for Successful Implementation of the Convention on the Rights of Persons with Disabilities on the Islamic World. Michigan Journal of International Law 35 (2), 443-483.

Mawdudi, Allamah Abu Al 'A'la. n.d. Human Rights in Islam. Retrieved from http://Www.Witness-Pioneer.Org/.

McCrudden, Christopher. 2008. Human Dignity and Judicial Interpretation of 
Human Rights. European Journal of International Law 19 (4), 655-724.

Musa, Imam Issa A. 2017. Disability: An Islamic Insight. Retrieved from http:// www.naseeb.com/villages/journals/article-from-australia-on-disability-andislam- 5380

Mutua, Makau. 2016. Human Rights Standards: Hegemony, Law and Politics. NY: New York University Press.

Nussbaum, Martha C. 2000. Woman and Human Rights Development: The Capabilities Approach. Cambridge: Cambridge University Press.

Nussbaum, Martha C. 2007. Frontiers of Justice: Disability, Nationality, Species Membership. Cambridge, Massachusetts: The Balknappers of Harvard University Press.

Oxford Advanced Learner's Dictionary of Current English, Sixth Edition, 2000. Oxford: Oxford University Press.

Oliver, Michael \& Barnes, Colin. 2012. The New Politics of Disablement. Basingstoke: Palgrave Macmillan. 21-23.

Pervez, Saulat. 2017. Disability in Islam; the Treatment of Handicapped People in Islam. Retrieved from http://www.whyislam.org/social-values-in-islam/social-ties/ disability-in-islam/

Quinn, Gerald \& Degener, Theresia. 2002. Human Rights and Disability: The Current Use and Future Potential of United Nations Human Rights Instruments in the Context of Disability. Geneva: Office of the High Commissioner for Human Rights.

Rehman, Javaid. n.d. The Right To Equality and Non-Discrimination in The Administration of Justice. Retrieved from http://www.ohchr.org/Documents/Publications/ training9chapter13en.pdf

Rioux, Marcia H.; Basser, Lee Ann \& Jones, Melinda. 2011. Critical Perspectives on Human Rights and Disability Law. Leiden: Martinus Nijhoff Publishers.

Rispler-Chaim, Vardit. 2007. Disability in Islamic Law. Dordrecht: Springer.

Shiuny, Fathimath. 2016. Human Rights Approach to Disability within Maldivian Legal Framework. Unpublished PhD Thesis International Islamic University. 
Stein, Michael A. 2007. Disability Human Rights. Califormia Law Review 95 (1), $75-121$.

Stein, Michael A \& Stein, Penelope J. S. 2007. Beyond Disability Civil Rights. Hastings Law Journal 58 (1), 1203-1240.

Sustainable Goals. n.d. Available in http://www.un.org/sustainabledevelopment/ sustainable-development-goals/

Tah, Ikmal Hisham Md. 2013. Rights of Persons with Disabilities in Malaysia: The Almost Forgotten Protection under the Federal Constitution in Mokhtar, Khairil Azmin (Ed.) Constitutional Law and Human Rights in Malaysia: Topical Issues and Perspectives. Selangor Sweet \& Maxwell Asia.

Turmusani, Majid. 2003. Disabled People and Economic Needs in the Developing World, A Political Perspective from Jordan. Oxford: Ashgate.

Waltz, Susan. 2004. Universal Human Rights: The Contribution of Muslim States. Human Rights Quarterly 26 (1), 799-844.

Yaqut, Muhammad Mus`ad. 2007. Caring for People with Special Needs in Islam. Retrieved from http://theislamicworkplace.com/2007/06/14/caring-forpeople-with-special-needs-in-islam/. 